\title{
PENERAPAN ASUHAN KEPERAWATAN PADA PASIEN Ny. N DENGAN DM TIPE II DALAM PEMENUHAN KEBUTUHAN NUTRISI DI RSUD LABUANG BAJI MAKASSAR
}

\author{
APPLICATION OF NURSING ASSISTANCE IN PATIENTS Ny. N WITH DM TYPE \\ II IN MEETING NUTRITION NEEDS IN RSUD LABUANG BAJI MAKASSAR
}

\author{
Nurlina \\ Akademi Keperawatan Muhammadiyah Makassar \\ Email: nurlinajamal@gmail.com
}

\begin{abstract}
Diabetes mellitus is a collection of symptoms that arise in a person caused by increased blood sugar levels (glucose) due to lack of insulin both absolute and relative. Recorded 220 countries worldwide, the number of diabetics is expected to rise from 415 million people in 2015 to 642 million in 2040. The occurrence of increased DM patients due to dietary changes, namely from traditional foods are healthy, high fiber, low fat, low calories, with increased consumption of calorie-containing foods such as simple carbohydrates, fat, red meat and low in fiber. The data indicate an increase in animal food supply and saturated fatty acid intake, especially in Asian countries.

This study aims to determine the results of the application of nursing care to $\mathrm{Ny}$. $\mathrm{N}$ with Type II Diabetes Mellitus in the fulfillment of nutritional needs in the Chamber of Pa'mai II of RSUD Labuang Baji Makassar.

The research method used is interview and observation method.

The results showed that the client appeared weak, decreased appetite, weight loss, nausea and vomiting, often feeling thirsty, tingling on both legs. After giving nursing care to Ny. $\mathrm{N}$ for the fulfillment of nutritional needs with 1700 calories / day in accordance with the diet program has not been fulfilled.
\end{abstract}

Keywords: Diabetes Mellitus, Nutritional Needs

\begin{abstract}
ABSTRAK
Diabetes melitus adalah suatu kumpulan gejala yang timbul pada seseorang yang disebabkan oleh karena adanya peningkatan kadar gula (glukosa) darah akibat kekurangan insulin baik absolut maupun relatif. Tercatat 220 negara diseluruh dunia, jumlah penderita diabetes diperkirakan akan naik dari 415 juta orang di tahun 2015 menjadi 642 juta pada tahun 2040. Terjadinya peningkatan penderita DM dikarenakan adanya perubahan pola makan, yaitu dari makanan tradisional yang sehat, tinggi serat, rendah lemak, rendah kalori, dengan meningkatnya konsumsi makanan mengandung kalori seperti karbohidrat sederhana, lemak, daging merah dan rendah serat. Data menunjukkan adanya peningkatan dalam persediaan makanan hewani dan asupan asam lemak jenuh terutama di Negara-negara Asia.

Penelitian ini bertujuan mengetahui hasil penerapan asuhan keperawatan pada $\mathrm{Ny} . \mathrm{N}$ dengan Diabetes Melitus Tipe II dalam pemenuhan kebutuhan nutrisi di Ruang Baji Pa'mai II RSUD Labuang Baji Makassar.
\end{abstract}


Metode penelitian yang digunakan adalah metode wawancara dan observasi. Hasil penelitian menunjukkan bahwa klien nampak lemah, nafsu makan menurun, penurunan berat badan, mual dan muntah, sering merasa haus, kesemutan pada kedua kakinya. Setelah pemberian asuhan keperawatan pada $\mathrm{Ny}$. $\mathrm{N}$ untuk pemenuhan kebutuhan nutrisi dengan $1700 \mathrm{kalori} / \mathrm{hari}$ sesuai dengan program diet belum terpenuhi.

Kata kunci: Diabetes Melitus, kebutuhan nutrisi

\section{PENDAHULUAN}

Diabetes Melitus (DM) merupakan sekelompok kelainan heterogen yang ditandai oleh kenaikan kadar glukosa dalam darah atau hipergelikemia. Diabetes Melitus adalah suatu kumpulan gejala yang timbul pada seseorang yang disebabkan oleh karena adanya peningkatan kadar gula (glukosa) darah akibat kekurangan insulin baik absolut maupun relatif (Hasdianah \& Suprapto, 2014)

Kasus Diabetes Melitus yang paling banyak dijumpai adalah Diabetes Melitus Tipe 2, yang ditandai dengan adanya gangguan sekresi insulin. Penyebab terjadinya DM Tipe 2 ini dipengaruhi oleh gaya hidup, genetik, dan stress psikososial. DM Tipe 2 merupakan tipe diabetes yang paling umum ditemukan pada pasien dibadingkan dengan DM Tipe 1 (Bustam, 2014)

\begin{tabular}{ccc}
\multicolumn{2}{c}{ Menurut World } & Health \\
Organization [WHO] (2014) & Jumlah
\end{tabular}

orang yang hidup dengan Diabetes dan prevalensinya meningkat di semua wilayah di dunia. Pada tahun 2014, berjumlah 422 juta orang dewasa (atau 8,5 $\%$ penduduk dunia) terserang Diabetes, dibandingkan pada tahun 2012 jumlah penderita sebanyak 1.5 juta orang. Prevalensi DM tertinggi terdapat di wilayah Mediterania Timur (14\%) dan terendah di Eropa dan wilayah Pasifik Barat (8\% - 9\%). Secara umum negara dengan penghasilan rendah menunjukkan angka prevalensi DM terendah dan negara dengan penghasilan menengah atas menunjukkan prevalensi DM tertinggi di dunia. Prevalensi DM di negara dengan pendapat menengah atas terbanyak di Negara Cooks Island $(29,1 \%)$, disusul Negara Niue (27,6\%). Prevalensi DM pada negara penghasilan menengah bawah terbanyak pada Negara Samoa (25,2\%), disusul Negara Micronesia (22,5\%). Prevalensi DM pada negara dengan pendapatan tinggi/atas terbanyak pada Negara Qatar (23\%), disusul Negara Kuwait $(20,1 \%)$ dan prevalensi DM pada negara dengan pendapatan rendah terbanyak pada Negara Taj Ikistan 
$(12,1 \%)$ disusul Negara Gambia dan Chad yaitu masing-masing $9,9 \%$.

Atlas Diabetes edisi ke-7 tahun 2015 dari International Diabetes Federation [IDF] menyebutkan bahwa dari catatan 220 negara diseluruh dunia, jumlah penderita diabetes diperkirakan akan naik dari 415 juta orang di tahun 2015 menjadi 642 juta pada tahun 2040 . Hampir setengah tersebut berada di Asia, terutama India, China, Pakistan, dan Indonesia. Angka penderita diabetes yang didapatkan di Asia Tenggara adalah Singapura 12,8\%, Thailand 8\%, Malaysia $16,6 \%$, dan Indonesia 6,2\%. Kalau pada tahun 2015 Indonesia berada di nomor tujuh sebagai Negara dengan jumlah pasien diabetes terbanyak di dunia, pada tahun 2040 diperkirakan Indonesia akan naik ke nomor enam terbanyak. Pada saat ini dilaporkan bahwa kota-kota besar seperti Jakarta dan Surabaya, sudah hampir $10 \%$ penduduknya mengidap penyakit Diabetes Melitus (Tandra, 2017)

Berdasarkan hasil Riset Kesehatan Daerah 2013 [Riskesda, 2013] bahwa penderita DM yang angka kejadian diabetesnya melebihi angka kejadian nasional (2,1 \%), tertinggi ada pada provinsi Sulawesi Tengah 3,7 \%, Sulawesi Utara $3.6 \%$, Sulawesi Selatan 3.4\%, Nusa
Tenggara Timur 3,3\%, dan DKI Jakarta $3,0 \%$.

Terjadinya peningkatan penderita DM dikarenakan adanya perubahan pola makan, yaitu dari makanan tradisional yang sehat, tinggi serat, rendah lemak, rendah kalori. Dengan meningkatnya konsumsi makanan mengandung kalori seperti karbohidrat sederhana, lemak, daging merah dan rendah serat. Data menunjukkan adanya peningkatan dalam persediaan makanan hewani dan asupan asam lemak jenuh terutama di Negaranegara Asia (Azrimaidaliza, 2011)

Penelitian yang dilakukan oleh Azrimaidaliza (2011), menyatakan bahwa penyakit Diabetes Melitus disebabkan oleh banyak faktor. Pengaturan pola makan, terutama konsumsi lemak, karbohidrat dan serat cukup akan membantu dalam mengontrol glukosa darah. Asupan zat gizi mikro, salah satunya vitamin $\mathrm{C}$ terdapat dalam makanan sumber alami, yang berperan sebagai antioksidan akan menurunkan resistensi dan melalui perbaikan fungsi endothelial dan menurunkan stress oksidatif sehingga mencegah perkembangan kejadian diabetes tipe 2 . Selain menerapkan pola makan sehat juga 
dianjurkan bagi masyarakat untuk melakukan olahraga secara teratur.

Dalam penelitian ini diharapkan dapat bermanfaat untuk membantu penderita DM dalam pemenuhan kebutuhan nutrisi dengan ukuran penyajian makanan secara tepat dan mandiri dengan pengaturan karbohidrat yang optimum sesuai dengan kadar insulin yang digunakan dan kebutuhan energi penderita DM sehingga sangat membantu dalam pengendalian glukosa darah dari waktu ke waktu. Pengaturan pola makan pada penderita DM melalalui Penerapan Asuhan Keperawatan pada Pasien sangat dibutuhkan agar jumlah penderitanya dapat menurun dari tahun ke tahun.

Mengetahui hasil penerapan asuhan keperawatan pada Ny. $\mathrm{N}$ dengan Diabetes Melitus Tipe 2 dalam pemenuhan kebutuhan nutrisi di Ruang Baji Pa'mai II RSUD Labuang Baji Makassar

METODE

Desain penelitian

Penelitian ini menggunakan rancangan studi kasus deskriptif. Data hasil penelitian disajikan dalam bentuk studi kasus dengan menggunakan pendekatan proses keperawatan dan dijabarkan dalam pelaksanaan asuhan keperawatan.

\section{Lokasi dan Waktu Penelitian}

1. Tempat Studi Kasus

Tempat pelaksanaan studi kasus di Ruang Baji Pa'mai II RSUD Labuang Baji Makassar.

2. Waktu Pelaksanaan Studi Kasus

Studi kasus dilaksanakan pada tanggal 18-23 Juli 2017.

\section{Subjek Studi Kasus}

Subyek studi kasus yang akan dikaji adalah pasien dengan Diabetes Melitus Tipe 2 yang mengalami gangguan pemenuhan kebutuhan nutrisi

\section{Cara Pengumpulan Data}

Metode pengumpulan data adalah cara yang digunakan peneliti dalam mengumpulkan data penelitian. Agar data dapat terkumpul dengan baik dan terarah, dilakukan pengumpulan data dengan metode wawancara dan observasi.

\section{HASIL}

Setelah dilakukan pengkajian pada Ny. N maka didapatkan data: Ny. N mengeluh badannya terasa lemas, luka pada bagian leher seperti bisul yang tidak 
sembuh-sembuh, pembengkakan daerah wajah sejak 2 minggu yang lalu. Sejak saat itu klien tidak pernah beraktivitas lagi seperti biasanya, nafsu makannya mulai menurun, klien mengalami kesulitan mengunyah dan menelan akibat luka pada mulut dan bengkak pada leher, sehari sebelum dibawa ke RS klien mengalami mual dan muntah sebanyak 2 kali dengan volume nasi bercampur air berwarna kekuning-kuningan. Ny. N sering merasakan haus dan kesemutan pada kedua kakinya, serta klien merasa badannya semakin kurus. Sekitar 6 bulan yang lalu BB: 56 kg, 1 bulan yang lalu BB: $50 \mathrm{~kg}$ sekarang BB turun menjadi $47 \mathrm{~kg}$.

Dari pemeriksaan pada Ny. N didapatkan keadaan umum lemah, tingkat kesadaran Composmentis dengan TD : 170/80 mmHg, Nadi: 80 x/i, Suhu: 37, $2^{0}$ C, Pernafasan: $22 \mathrm{x} / \mathrm{i}$, TB: $160 \mathrm{~cm}$, dengan IMT: $18,3 \mathrm{~kg} / \mathrm{m}^{2}$. hasil pemeriksaan penunjang pada tanggal 18/07/2017 dengan hasil GDS: 296 mg/dl, GDP: 260 mg/dl, SGPT: 16 U/L, Kreatinin: 0,52 mg/dl, Hemoglobin: 10,6 g/dl, Pengobatan yang diberikan adalah terapi insulin Novarapid 6 unit dengan 3 kali/hari diberikan 2 jam sebelum makan. Ranitidin dengan dosis $50 \mathrm{mg}$ setiap 6 jam.
Berdasarkan hasil pengkajian yang didapatkan dari Ny. N maka diagnosa keperawatan yang muncul adalah perubahan nutrisi kurang dari kebutuhan tubuh berhubungan dengan ketidakcukupan insulin dan penurunan asupan oral, sehingga dilakukan penerapan asuhan keperawatan pada $\mathrm{Ny}$. $\mathrm{N}$ untuk dapat memebantu meningkatkan derajat kesehatannya.

Setelah dilakukan tindakan keperawatan pada Ny. N, maka dilanjutkan dengan evaluasi, dengan hasil evaluasi akhir dengan masalah perubahan nutrisi kurang dari kebutuhan tubuh berhubungan dengan ketidakcukupan insulin dan penurunan asupan oral teratasi, dengan kriteria: Klien mengatakan nafsu makan sudah baik, tidak ada mual dan muntah, tidak sulit menelan, makan sesuai program diet yang dianjurkan, klien nampak tidak lemas lagi. TD: 150/80 mmHg, N: 80 x/i, S: 37, $2^{\circ} \mathrm{C}, \mathrm{P}: 22$ x/i. IMT: $18,75 \mathrm{~kg} / \mathrm{m}^{2}, \mathrm{BB} 48 \mathrm{Kg}$ (BB ideal 48-50 kg). Dengan kadar glukosa darah sewaktu 197 mg/dl. Maka intervensi dapat dipertahankan dan dilanjutkan sesuai dengan kondisi pasien.

\section{PEMBAHASAN}


Setelah dilakukan pengkajian pada

$\mathrm{Ny}$. $\mathrm{N}$ maka didapatkan keluhan sebagai berikut:

a. Klien mengatakan badannya terasa lemas disebabkan karena kurang asupan makan yang masuk dalam tubuh yang dihasilkan sebagai energi sehingga mengalami kelemahan dan keletihan. Hal ini sejalan dengan pendapat Putri \& Wijaya (2013) bahwa rasa lemah disebabkan glukosa dalam darah tidak dapat masuk ke dalam sel, sehingga sel kekurangan bahan bakar untuk menghasilkan tenaga.

b. Klien mengatakan belum mengetahui secara pasti penurunan nafsu makan yang dialami, jadi klien menganggap penurunan nafsu makan karena kesulitan dalam menelan. Menurut Juwono, Scheiber, \& Widijanto (2011), anoreksia atau penurunan nafsu makan walaupun terdapat kebutuhan fisiologis akan makanan, adalah gejala gastroentritis yang umum dan merupakan gangguan endokrin serta merupakan ciri dari gangguan psikologis tertentu. Anoreksi biasanya muncul secara bertahap dan diserta dengan kulit kering, kemerahan, napas beraroma buah-buahan , polidipsia, poliuria, nokturia, hipotensi, denyut lemah dan cepat, mulut kering, nyeri abdomen, muntah, dan perubahan tingkat kesadaran.

c. Klien mengatakan penurunan berat badan disebabkan karena nafsu makan menurun dan kurangnya asupan energi dalam tubuh yang digunakan sebagai tenaga sehingga sumber tenaga diambil dari sel lemak dan otot. Pendapat dari Putri \& Wijaya (2013), bahwa penurunan berat badan yang berlangsung relatif singkat harus menimbulkan kecurigaan, hal ini disebabkan karena sel kekurangan bahan bakar untuk menghasilkan tenaga, untuk kelangsungan hidup, sumber tenaga terpaksa diambil dari cadangan lain yaitu sel lemak dan otot. Akibatnya penderita kehilangan jaringan lemak dan otot sehingga menjadi kurus. Sedangkan menurut Tandra (2017), bahwa berat badan turun sebagai kompensasi dari dehidrasi 
dan banyak minum. Pada mulanya berat badan makin meningkat, tetapi lama kelamaan otot tidak mendapat cukup gula untuk tumbuh dan mendapatkan banyak energi. Maka jaringan otot dan lemak harus dipecah untuk memenuhi kebutuhan energi. Berat badan menjadi turun, meskipun banyak makan. Keadaan ini makin diperburuk oleh adanya komplikasi yang timbul.

Saat dilakukan pengkajian berat badan klien $47 \mathrm{~kg}$ dan setelah dilakukan perawatan selama tiga hari berat badan naik $1 \mathrm{~kg}$ menjadi $48 \mathrm{~kg}$, kenaikan berat badan ini bukan secara fisiologis karena disebabkan oleh edema pada kedua ekstremitas bawahnya. Secara fisiologis berat badan naik 0.5-1 kg dalam satu minggu jika patuh terhadap program diet yang diberikan agar mencapai berat badan ideal.

d. Klien mengatakan munculnya luka pada bagian leher seperti bisul yang tidak sembuh-sembuh disebabkan karena pengaruh kadar gula yang tinggi sehingga mengalami infeksi. Hal ini sejalan dengan pendapat Tandra (2017), bahwa penyebab luka yang sukar sembuh pada penderita DM adalah infeksi yang hebat, kuman atau jamur yang mudah tumbuh pada kondisi gula darah yang tinggi. Kerusakan pembuluh darah, aliran darah yang tidak lancar pada kapiler (pembuluh darah kecil) yang menghambat penyembuhan luka. Kerusakan saraf dan luka yang tidak terasa menyebabkan penderita diabetes tidak menaruh perhatian padanya dan membiarkannya makin memburuk. Sedangkan menurut Putri \& Wijaya (2013), bahwa kelainan kulit berupa gatal, biasanya terjadi di daerah kemaluan dan daerah lipatan kulit seperti ketiak dan di bawah payudara. Sering pula dikeluhkan timbulnya bisul dan luka yang lama sembuh. Luka ini dapat timbul karena akibat hal yang sepele seperti luka lecet karena sepatu atau tertusuk peniti.

e. Klien mengatakan sering merasakan kesemutan pada kedua kakinya hal ini disebabkan karena kurangnya aktivitas yang 
dilakukan sehingga peredaran darah tubuh tidak lancar dan mungkin karena pengaruh kadar gula darah yang tinggi. Sedangkan menurut Tandra (2017), bahwa kerusakan saraf yang disebabkan oleh gula yang tinggi merusak dinding pembuluh darah dan akan mengganggu nutrisi pada saraf, karena yang rusak adalah saraf sensoris, keluhan yang paling sering muncul adalah rasa kesemutan atau tidak terasa, terutama pada bagian tangan dan kaki. Selanjutnya bisa timbul nyeri pada anggota tubuh, betis, kaki, dan lengan, bahkan kadang terasa seperti terbakar.

f. Klien mengatakan pengaruh dari sering kehausan karena banyak cairan yang keluar melalui kencing dan tenggorakannya terasa kering sehingga klien banyak minum untuk menghilangkan rasa haus tersebut. Menurut Tandra (2017) untuk mengatasi dehidrasi dan rasa haus yang timbul maka diperluka banyak minum. Kesalahan yang sering dijumpai pada penderita adalah untuk mengatasi rasa haus, mencari softdrink yang manis dan segar. Akibatnya, gula darah makin naik dan hal ini dapat menimbulkan komplikasi akut yang membahayakan.

g. Klien mengatakan kesulitan menelan dan mengunyah disebabkan Karena luka pada leher sehingga sulit untuk menggerakkan rahangnya.

h. Klien mengalami mual dan muntah satu hari sebelum di bawa ke RS karena kurang asupan makanan yang masuk ke dalam tubuh mengakibatkan asam lambung mengalami peningkatan, saat dilakukan pengkajian, tidak ada lagi mual dan muntah karena sudah diberikan ranitidin untuk mencegah terjadinya peningkatan asam lambung.

i. Dari pemeriksaan penunjang hasil GDS: $296 \mathrm{mg} / \mathrm{dl}$ dan hari kedua turun menjadi $195 \mathrm{mg} / \mathrm{dl}$, karena telah diberikan program diet sesuai dengan kebutuhan sebanyak 1700 kalori/hari dan pemberian terapi insulin sehingga kadar gula darah dapat turun. Menurut penelitian Idris, Indriasari, \& Jafar (2015) Hasil dari penelitian bahwa ada hubungan pola makan seperti 
asupan energi, karbohidrat, lemak, protein dan indeks glikemik dengan kadar gula darah pasien DM tipe 2 di wilayah kerja puskesmas Kota Makassar Tahun 2014.

Setelah dilakukan pengkajian pada hari ketiga kadar glukosa sewaktu Ny. N naik dari 195 mg/dl menjadi 210 mg/dl, hal disebabkan karena saat selesai makan, klien sering mengkonsumsi bauh-bauhan seperti pisang, semangka, dan buah pear. Menurut penelitian Astuti \& Maulani (2017), bahwa pangan indeks glikemik tinggi mempunyai hubungan yang signifikan terhadap kadar glukosa darah pasien DM tipe II, dimana pasien DM tipe II yang mengkonsumsi pangan indeks glikemik tinggi memiliki kadar glukosa darah yang tinggi.

Berdasarkan pengkajian yang dilakukan pada Ny. N maka diagnosa keperawatan yang ditemukan adalah perubahan nutrisi kurang dari kebutuhan tubuh berhubungan dengan ketidakcukupan insulin dan penurunan asupan oral.

Menurut Nurarif \& Kusuma (2015), adapun batasan karakteristik dari diagnosa ketidakseimbangan nutrisi kurang dari kebutuhan tubuh, adalah kram abdomen, nyeri abdomen, menghindari makanan, berat badan $20 \%$ atau lebih dibawah berat badan ideal, kerapuhan kapiler, diare, kehilangan rambut berlebihan, bising usus hiperaktif, kurang makanan, kurang informasi, kurang minat pada makanan, penurunan berat badan dengan asupan makanan adekuat, kesalahan konsepsi, ketidakmampuan memakan makanan, tonus otot menurun, mengeluh gangguan sensasi rasa, mengeluh asupan makanan kurang dari RDA, cepat kenyang setelah makan, sariawan pada rongga mulut, kelemahan otot mengunyah, dan kelemahan otot menelan.

Menurut Tarwoto (2012). Ada 15 rencana tindakan yang dapat dilakukan untuk diagnosa perubahan nutrisi kurang dari kebutuhan tubuh berhubungan dengan ketidakcukupan insulin dan penurunan asupan oral adalah sebagai berikut:

a. Kaji status nutrisi pasien, rencana ini dilakukan untuk menentukan kebutuhan nutrisi pasien. Menurut Damayanti (2015) penatalaksaan nutrisi di mulai dari menilai kondisi pasien, salah satunya menilai status gizi, penilaian status gizi dengan menghitung IMT 
untuk melihat apakah penderita DM mengalami kegemukan dan obesitas.

b. Observasi Tanda-tanda Vital, Mengetahui keadaan umum klien karena tekanan darah dapat berpengaruh pada peningkatan kadar gula pada pasien. Menurut Damayanti (2015), bahwa seseorang yang beresiko menderita DM adalah yang mempunyai tekanan darah tinggi (hipertensi) yaitu tekanan darah $\geq$ 140/90 mmHg pada umumnya penderita DM juga menderita hipertensi. Hipertensi yang tidak dikelola dengan baik akan mempercepat kerusakan pada ginjal dan kelainan kardiovaskuler. Sebaliknya apabila tekanan tidak dapat dikontrol maka akan memproteksi terhadap komplikasi mikro dan makrovaskuler yang disertai pengelolaan hiperglikemia yang terkontrol.

c. Timbang berat badan pasien dan lakukan secara berkala 3 hari sekali atau sesuai indikasi, intervensi ini dilakukan untuk menentukan Basal Massa Indeks dan merencanakan terapi nutrisi. Menurut Tandra (2017), perubahan berat badan yang cepat bisa merupakan indikasi perubahan dalam kontrol gula darah. Kenaikan berat bisa menandakan gula darah yang mulai turun, mungkin juga lantaran asupan kalori dalam makanan anda yang berlebihan serta kurang berolahraga. Sedangkan berat badan yang turun bisa disebabkan oleh gula darah yang tinggi, komplikasi pada paruparu, liver, atau organ tubuh lainnya, disamping kemungkinan penyakit lain seperti hipertiroid, depresi, atau gangguan pencernaan.

d. Anjurkan makan sedikit tapi sering, hal ini dilakukan agar dapat membantu mengendalikan energi dan pemenuhan nutrisi. Menurut penelitian Pratidina (2013), bahwa Subjek motivasi makan pasien dengan kategori baik sebesar $53,3 \%$ dan sisa makan banyak terdapat pada jenis makanan pokok dan sayur sebesar $60 \%$, serta lauk nabati sebesar 53,3\%. Maka tidak ada hubungan antara 
motivasi makan pasien dengan sisa makanan, tetapi ada hubungan antara lama perawatan dengan sisa makanan.

e. Ukur Body Massa Indeks pasien, intervensi ini dilakukan untuk mengetahui kebutuhan nutrisi tubuh klien karena ditentukan juga oleh BMI. Dari hasil penelitian Priasmara (2015), menunjukaan distribusi frekuensi kadar gula darah pada lansia di Gelora Tri Lomba Juang rata-rata 139,92 $\mathrm{mg} / \mathrm{dl}$ dan rata-rata IMT 25,24 $\mathrm{kg} / \mathrm{m}^{2}$. Hasil penelitian menunjukkan IMT berhubungan dengan variabel kadar gula darah sewaktu dengan nilai koefisien korelasi (r) sebesar 0,614 dan nilai signifikansi $(\alpha)$ sebesar 0,034 maka terdapat hubungan.

f. Identifikasi faktor-faktor yang mempengaruhi status nutrisi pasien, dilakukan untuk mengetahui penyebab kurang nutrisi dan merencakan pemenuhan nutrisi.

g. Monitori gula darah pasien secara periodik sesuai indikasi, intervensi ini dapat dilakukan karena perubahan kadar gula darah dapat terjadi setiap saat serta dapat menentukan perencanaan kebutuhan kalori. Menurut Damayanti (2015) pemantauan kadar glukosa dalam darah memungkinkan untuk mendeteksi dan mencegah hiperglikemia atau hipoglikemia, pada akhirnya akan mengurangi komplikasi diabetik jangka panjang. Pemeriksaan ini dianjurkan bagi pasien dengan penyakit DM yang tidak stabil, kecenderungan untuk mengalami ketosis berat, hiperglikemia dan hipoglikemia tanpa gejala ringan. Kaitannya dengan pemberian insulin, dosis insulin yang diperlukan pasien ditentukan oleh kadar glukosa darah yang akurat.

h. Kaji pengetahuan pasien dan keluarga tentang diet diabetik. Hal ini perlu dilakukan untuk mengetahui sejauh mana pengetahuan keluarga dan klien tentag penyakit DM, karena pasien DM rentang terjadi komplikasi sehingga pasien dan keluarga harus memahami komplikasi akut dan kronik. Menurut penelitian Rahmawaty, Witasari, \& Zulaekah (2009), bahwa tidak ada hubungan 
tingkat pengetahuan tentang pengelolaan DM dengan pengendalian kadar glukosa darah puasa penderita DM Tipe II, Tetapi ada hubungan antara tingkat pengetahuan tentang pengelolaan DM dengan pengendalian kadar glukosa darah 2 jam post prandial penderita DM Tipe 2.

i. Kaji pola makan dan aktivitas pasien, intervensi perlu dilakukan karena faktor yang dapat mempengaruhi kadar glukosa darah pada klien adalah pola makan dan aktivitas. Aktivitas latihan yang rutin membantu menurunkan komplikasi penyakit jantung dan menurunkan kadar gula darah. Dari hasil penelitian Idris, Indriasari, \& Jafar (2015) Hasil penelitian bahwa ada hubungan pola makan asupan energi, karbohidrat, lemak, protein, dan indeks gikemik dengan kadar gula darah pasien DM tipe 2 di wilayah kerja puskesmas Kota Makassar Tahun 2014. Menurut Damayanti (2015) aktivitas fisik yang kurang menyebabkan resistensi insulin pada DM Tipe 2. Aktivitas fisik dapat berdampak terhadap aksi insulin pada orang berisiko.

j. Konsultasikan ahli diet untuk mengidentifikasi dan merencanakan kebutuhan nutrisi pasien, ini perlu dilakukan karena ahli gizi lebih kompeten dalam penentuan dan merencanakan kebutuhan nutrisi pasien. Menurut penelitian Budi, Purba, \& Widya (2015) perubahan kualitas diet kelompok kontrol berbeda signifikan dengan perubahan kualitas diet pada kelompok perlakuan. Konseling gizi individu dan kelompok memperbaiki kualitas diet pada pasien diabetes mellitus. Konsumsi sayur, buah, susu, daging, dan kacangkacangan mengalami peningkatan yang signifikan pada kelompok perlakuan. Hal ini disebabkan adanya pemberian edukasi diet seimbang diabetes melitus pada sesi konseling yang dijalani oleh subjek.

k. Libatkan pasien dan keluarga dalam merencanakan kebutuhan nutrisi, intervensi ini perlu dilakukan karena klien dapat 
menentukan sesuai dengan sumber daya yang dimiliki dan memberikan keyakinan rencana program nutrisi dapat dilaksanakan.

1. Laksanakan program terapi seperti pemberian obat antidiabetik atau insulin, intervensi ini dapat dilakukan setiap hari guna menstabilkan kadar glukosa dalam darah dan pengobatan merupakan bagian yang tidak terpisahkan dari peningkatan status nutrisi pasien. Menurut Hasdiana dan Suprapto (2014) tujuan utama terapi diabetes melitus adalah mencoba menormalkan aktivitas insulin dan kadar glukosa darah dalam upaya untuk mengurangi komplikasi vaskuler serta neuropati.

m. Monitoring adanya tanda-tanda hipoglikemia, intervensi ini perlu dilakukan karena setelah pemberian obat antidiabetik atau insulin bisa menimbulkan hipoglikemia. Pendapat Tandra (2017) bahwa penyebab hipoglikemia adalah penderita diabetes yang diobati dengan suntikan insulin ataupun minum obat tablet antidiabetis, tetapi tidak makan dan olahraganya melebihi takarannya. Keluhan dan gejala hipoglikemia dapat bervariasi, tergantung sejauh mana gula darah turun, keluhan akibat otak tidak mendapat cukup kalori sehingga mengganggu fungsi intelektual antara lain sakit kepala, kurang konsentrasi, mata kabur, capek, bingung, kejang, atau koma. Berikan pendidikan kesehatan tentang diet DM, obat-obatan dan resiko tidak menaati apa yang sudah diprogramkan dan program aktivitas, hal ini dilakukan untuk menambah pengetahuan penderita DM ataupun kepada keluarga sehingga dapat mengontrol kadar gula darah dengan baik dan pencegahan terjadinya komplikasi.

n. Berikan dukungan positif jika pasien mampu melaksanakan program nutrisi dengan benar, perencanaan ini dilakukan agar klien termotivasi dan percaya diri untuk tetap melaksanakan program diet. Menurut penelitian Sulistyarini \& Susanti (2013), berdasarkan hasil analisis dari penelitian dan yang telah dilakukan diketahui bahwa 
dukungan keluarga dapat

meningkatkan kepatuhan diet pada

pasien Diabetes Melitus di RS.

Baptis Kediri.

Evaluasi dilakukan berdasarkan teori yang ditentukan dari tujuan dan kriteria hasil yang ingin dicapai sesuai dengan rencana keperawatan. Pada kasus Ny. N dengan Diabetes Melitus setelah dilakukan evaluasi maka diperoleh data: nafsu makan klien mulai membaik, tidak ada mual dan muntah, BB: $48 \mathrm{~kg}$, IMT: $18,75 \mathrm{~kg} / \mathrm{m}^{2}$, dengan kadar glukosa darah 197 mg/dl. Sedangkan tujuan dan kriteria hasil yang ingin dicapai berdasarkan teori adalah kebutuhan nutrisi pasien terpenuhi, dengan kriteria hasil klien mengungkapkan tidak ada mual dan muntah, nafsu makan baik, berat badan pasien dalam rentang ideal (berat badan yang harus dicapai 49-50 kg), intake makanan sesuai dengan kebutuhan tubuh, Indeks Massa Tubuh (IMT) 19-22 kg/m², tidak ada tanda-tanda malnutrisi, kadar glukosa tubuh dalam rentang toleransi. Menurut Handayaningsih (2009) evaluasi sebagian yang direncanakan, dan perbandingan yang sistematik pada status kesehatan klien. Dengan mengukur perkembangan klien dalam mencapai suatu tujuan, maka perawat bisa menentukan efektifitas tindakan keperawatan. Dengan demikian diagnosa keperawatan perubahan nutrisi kurang dari kebutuhan tubuh berhubungan dengan ketidakcukupan insulin dan penurunan asupan oral, mulai teratasi.

\section{KESIMPULAN}

1. Data yang didapatkan dari hasil pengkajian dari $\mathrm{Ny}$. $\mathrm{N}$ dengan keluhan badan terasa lemas, nafsu makan menurun, mengalami penurunan berat badan, luka pada bagian leher seperti bisul yang tidak sembuh-sembuh,, kesulitan menelan dan mengunyah, mual, muntah, merasakan kesemutan pada kedua kakinya sering merasakan haus dan sering BAK, konjungtiva pucat berat badan $47 \mathrm{~kg}$, IMT: 18,3 $\mathrm{kg} / \mathrm{m}^{2}$. Hasil pemerikasaan penunjang GDS: $296 \mathrm{mg} / \mathrm{dl}$, GDP : $260 \mathrm{mg} / \mathrm{dl}$, SGPT : 16 U/L, Kreatinin : 0,52 mg/dl, Hemoglobin: 10,6 g/dl. Pada umumnya data yang ditemukan timbul sebagai akibat kekurangan insulin.

2. Diagnosa. keperawatan yang ditemukan pada Ny. N adalah perubahan nutrisi kurang dari kebutuhan tubuh berhubungan dengan ketidakcukupan insulin dan penurunan asupan oral. Dari data yang didapatkan 
hanya satu diagnosa keperawatan yang dapat dirumuskan karena peneliti berfokus pada gangguan nutrisi pada klien

3. Rencana tindakan pada $\mathrm{Ny}$. $\mathrm{N}$ dengan Diabetes Melitus, intervensi yang dibuat berdasarkan diagnosa keperawatan yang muncul. Sebanyak 15 intervensi yang dapat disusun berdasarkan masalah yang ada, yang bertujuan untuk memenuhi kebutuhan nutrisi pada klien.

4. Dalam pelaksanaan tindakan keperawatan pada $\mathrm{Ny}$. $\mathrm{N}$ dilakukan sesuai dengan rencana keperawatan yang telah dibuat dalam melakukan perawatan.

5. Evaluasi terhadap proses yang dilakukan untuk mengetahui perkembangan kondisi klien, pada kasus Ny. $\mathrm{N}$ setelah dilakukan tindakan keperawatan selama 6 hari maka masalah perubahan nutrisi kurang dari kebutuhan tubuh berhubungan dengan ketidakcupan produksi insulin dan penurunan asupan oral mulai teratasi.

\section{SARAN}

1. Saat melakukan pengkajian disarankan kepada perawat perlu ditingkatkan pendekatan kepada klien maupun keluarga dalam mengkaji masalah-masalah untuk memudahkan dalam penerapan asuhan keperawatan.

2. Dalam perumusan diagnosa keperawatan harus sesuai dengan datadata yang ditemukan saat pengkajian agar masalah pada klien dapat teratasi sesuai dengan yang diharapkan

3. Untuk menyusun perencanaan, perawat perlu memperhatikan hal-hal dalam penyusunan dan penentuan prioritas dan tujuan sesuai dengan masalah klien.

4. Pelaksaan tindakan keperawatan dilaksanakan berdasarkan intervensi yang telah disusun yang sesuai dengan kebutuhan klien

5. Diharapkan kepada perawat dalam melakukan evaluasi keperawatan meninjau kembali tujuan dan kriteria hasil dari intervensi yang telah dibuat setelah melakukan implementasi sebagai acuan untuk menilai perkembagan dari kondisi klien.

\section{UCAPAN TERIMA KASIH}

Penulis mengucapkan terima kasih kepada semua pihak yang telah membantu dalam pelaksanaan peneliotian ini. 


\section{DAFTAR PUSTAKA}

Astuti, A., \& Maulani. (2017). Pangan Indeks Glikemik Tinggi dan Kadar Gula Darah Pasien Diabetes Melitus Tipe 2, Doi:http//doi.org/10.222 16/jen. V 2i2.1956. diakses dari http:// ejournal.kopertis10.or. id/index. Php lendurance / article / download / 1956 / 725.

Azrimaidaliza. (2011). Asupan Gizi dan Penyakit Diabetes Melitus. Kesehatan Masyarakat. 37. Vol. 6, No. 1. Diakses dari http://download.portalgaruda.org/article.php?article=284144\&val=7056\&t itle=ASUPAN\%20ZAT\%20GIZI\%20DAN\%20PENYAKIT\%20DIABET ES\%20MELLITUS

Budi, L., Purba, M. B., \& Widya, S. (2015). Konseling Gizi Mempengruhi Kualitas Kualitas Diet Pasien Diabetes Melitus Tipe 2 di RSUD Dr. Sardjito Yogyakarta, 38, Vol. 3. No. 1 Januari 2015. Diakses dari http://ejournal.almaata.ac.id/index.php/IJND/article/download/304/276

Bustam, K. A. (2014). Tipe II Diabetes Melitus With Obesity Grade I In Elderly Woman. Medula. 46. Volume 2, Nomor 4, Juni 2014. Diakses dari http://repository.usu.ac.id/bitstream/123456789/3720/1/fkm-hiswani4.pdf

Damayanti, S. (2015). Diabetes Melitus \& Penatalaksanaan Keperawatan . Yogyakarta: Nuha Medika.

Handayaningsih, I. (2009). Dokumentasi Keperawatan "DAR". Jogjakarta: Mitra Cendikia Press.

Hasdianah, \& Suprapto, S. I. (2014). Patologi \& Patofisiologi Penyakit. Yogyakarta: Nuha Medika.

Idris, A. M., Indriasari, R., \& Jafar, N. (2015). Hubungan Pola Makan Dengan Kadar Gula Darah Pasien Rawat Jalan DM Tipe 2 Di Wiliyah Kerja Puskesmas Kota Makassar. Diakses dari https://core.ac.uk/download/pdf/25495818.pdf 
Juwono, A. L., Scheiber, Y., \& Widijanto, G. (2011). Nursing: Menafsirkan TandaTanda dan Gejala Penyakit. Jakarta Barat: Indeks.

Kusuma, H., \& Nurarif, A. H. (2015). Aplikasi Asuhan Keperawatan Diagnosa Medis \& NANDA NIC-NOC. Yogyakarta: MediAction.

Pratidina, D. (2013). Motivasi Makan Pasien, Lama Perawatan dan Sisa Makan Pasien Diabetes Militus Tipe 2 di RS PKU Muhammadiyah Surakarta, 8. Diakses dari http://eprints.ums.ac.id/27914/16/NASKAH_PUBLIKASI.pdf.

Priasmara, Y. D. (2015). Hubungan IMT dengan Kadar Gula Darah pada Lansia di Kota Semarang Tahun 2014. Diakses dari http://lib.unnes.ac.id/21263/1/6211410023-S.pdf.

Putri, Y. M., \& Wijaya, A. S. (2013). KMB 2 Keperawatan Medikal Bedah . Yogyakarta: Nuha Medika.

Rahmawaty, S., Witasari, U., \& Zulaekah, S. (2009). Hubungan Tingkat pengetahuan asupan karbohidrat dan serat dengan pengendalian kadar glukosa darah pada penderita diabetes melitus tipe 2. Jurnal Penelitian Sains dan Teknologi. Vol. 10, No. 2, 2009. 137. Diakses dari http://www.academia.edu/2553755/HUBUNGAN_TINGKAT_PENGETA HUAN_ASUPAN_KARBOHIDRAT_DAN_SERAT_DENGAN_PENGE NDALIAN_KADAR_GLUKOSA_DARAH_PADA_PENDERITA_.

Sulistyarini, T., \& Susanti, M. L. (2013). Dukungan Keluarga Meningkatkan Kepatuhan Diet Pasien Diabetes Melitus Di Ruang Rawat Inap RS. Baptis Kediri. Jurnal STIKES. Volume 6, No. 1, Juli 2013. Diakses dari http://puslit2.petra.ac.id/ejournal/index.php/stikes/article/view/18840/1857

Tandra, H. (2017). Segala Sesuatu yang Harus Anda Ketahui Tentang Diabetes . Jakarta: Gramedia Pustaka Utama. 
Tarwoto. (2012). Keperawatan Medikal Bedah Gangguan Sistem Endokrin. Jakarta Timur: CV. Trans Info Media. 
